\title{
MicroRNAs HSA-MIR-34A AND HSA-MIR-124 AS BIOMARKERS FOR PREDICTING AND MONITORING THE LITHIUM TREATMENT IN BIPOLAR DISORDER: IN SILICO ANALYSIS
}

\author{
ORCUN AVSAR \\ Hitit University, Department of Molecular Biology and Genetics, Corum, Turkey; \\ e-mail: orcunavsar.gen@gmail.com
}

Received: 14 July 2020; Accepted: 17 December 2020

Lithium is known to be efficient in treatment for mental disorders in people with bipolar disorder. The aim of the study was to identify bipolar disorder-specific microRNAs (miRNAs) that are associated with genes targeted by lithium treatment and lead to variance in the clinical response. miRNAs which are experimentally validated and shown to have differential expression pattern in bipolar disorder were selected from online public databases miRTarbase and HMDD v3.2. Target prediction was carried out for each miRNA, and experimentally validated miRNA-target $m R N A$ pairs were obtained and analyzed by miRTarbase, HMDD v3.2, TargetScan, and DIANA databases. miRNA-target genes that are associated with lithium was determined by the use of DrugBank. According to the in silico analysis, it has been found that IMPA1 gene was targeted by hsa-mir-34a and GRIA3 gene was targeted by hsa-mir-124. The present study demonstrated that IMPA1, GRIA3, hsa-mir-34a, hsa-mir-124 may have the potential to be used as molecular biomarkers for estimating and monitoring the response to lithium treatment in bipolar disorder.

K e y w o rd s: bipolar disorder, lithium, IMPA1, GRIA3, miRNA hsa-mir-34a, miRNA hsa-mir-124.

$\mathrm{B}$ ipolar disorder (BD) which is a severe, common and chronic neuropsychiatric disorder with a heritability of approximately $70 \%$ is characterized by depression and mania [1]. The onset of $\mathrm{BD}$ is typically in adolescence or early adulthood and the physical and mental health, interpersonal relations, occupational and educational functioning of the patient is affected [2]. BD occurs in nearly $1 \%-3 \%$ of population and the prevalence is equal in males and females. Bipolar disorder is multifactorial and complex disease with unclear aetiology [3].

Mood stabilizers are used for the treatment of bipolar disorder and among them, lithium is used for the prevention of depressive and manic episodes, death by suicide, suicide attempts, and has the strongest potential for the prevention of long-term relapse. On the other hand, response of lithium treatment is highly variable, $30-40 \%$ of patients fail to respond and it has been supposed that genetic background is important for the variation of the lithium response. Even though, lithium has long been used in order to treat bipolar disorder, the molecular mechanisms underlying its therapeutic effect is poorly understood $[4,5]$.

MicroRNAs (miRNAs) which are composed of approximately 22 nucleotides are endogenous noncoding small RNA molecules and modulate gene expression. miRNAs were discovered in developmental studies conducted with Caenorhabditis elegans in 1993. Gene and protein expression is regulated by miRNAs by target mRNA cleavage, translational repression or mRNA deadenylation. Therefore, cellular miRNAs are participated in the regulation of numerous biological processes such as differentiation, cell proliferation, development, and apoptosis, and dysregulation of miRNAs has been correlated with various diseases such as cancer [6]. It has been suggested that miRNAs are potential predictors of response of treatment in multifactorial disorders. Moreover, microRNAs are involved in biological

(c) 2021 Orcun Avsar. This is an open-access article distributed under the terms of the Creative Commons Attribution License, which permits unrestricted use, distribution, and reproduction in any medium, provided the original author and source are credited. 
pathways that modulate synaptogenesis, neuronal differentiation, and neurogenesis. Alterations in miRNA expression in response to lithium have been investigated in various studies $[4,7]$. Hence, miRNA expression analysis may be used to modulate drug treatment in order to obtain optimal response in BD patients.

The aim of the present study was to identify bipolar disorder-specific miRNAs that are associated with genes targeted by lithium treatment and lead to variance in the response and to better understand the molecular mechanism of action of lithium response and the genetic variation that affects clinical response. In this regards, it has been hypothesized that miRNA expression might serve as a potential biomarker to estimate treatment efficacy in BD.

\section{Materials and Methods}

Selection of miRNAs that are implicating in bipolar disorder. MicroRNAs (miRNAs) which are experimentally validated and shown to have differential expression pattern in bipolar disorder were selected from online public databases i.e. miRTarbase and HMDD v3.2: the Human microRNA Disease Database version3.2. miRTarbase database provides extensive information about experimentally validated miRNA-target interactions [8]. HMDD database which is freely accessible obtains a remarkable number of miRNA-disease correlation entries from the literature in a manuel way [9].

Analyis of BD-specific-miRNA targets. Target prediction was carried out for each miRNA and experimentally validated miRNA-target mRNA pairs were obtained and analyzed by miRTarbase, HMDD v3.2, TargetScan, and DIANA databases. miRNA targets are generally identified via pairing between complementary regions in target mRNAs and miRNA seed sites. TargetScan that is freely available resource provides comprehensive information about miRNAs of human, zebrafish, mouse, and the other vertebrates and their individual generegulatory networks [10]. DIANA web tool is used for miRNA functional investigation. This database is utilized in order to determine targets of interest and to identify miRNA functions. The most frequently applied databases and algorithms involve DIANATarBase V7.0, DIANA-miRPath v3.0, DIANA-microT-CDS, DIANA-lncBase v2.0, DIANA-mirExTra v2.0, DIANA-miRGen v3.0 [11].

miRNA target genes as drug-targets. We determined the miRNA-target genes that are associated with lithium by the use of DrugBank. The online web-tool DrugBank is a database involving extensive molecular information about drugs, their targets, molecular mechanisms, and interactions and first idetified in 2006 [12].

\section{Results and Discussion}

Bipolar disorder is a serious, complex and highly heritable mental pathology. Bipolar disorder and its proper treatment have importance for the patient, the family and the society because of its chronic and recurrent course. World Health Organization (WHO) has declared that BD is one of the most common neuropsychiatric disorders for the individuals age with 15-44 [13]. Lithium has been used in order to treat bipolar disorder for approximately six years and still one of the most effective drug for BD [14]. On the other hand, 30-40\% of BD patients do not respond to lithium and many patients show serious side effects such as thyroid suppression, acne, renal impairment, and weight gain because of genetic variations [15]. The underlying molecular mechanisms of $\mathrm{BD}$ is unclear. It has been determined that expression levels of numerous miRNAs are altered in the several samples of bipolar disorder patient. Hence, it has been suggested that miRNAs have potential roles for the pathogenesis of BD [16]. Therefore, it was reasoned that defining the target genes of BDspecific miRNAs and lithium-targeted genes might provide remarkable insights into the fundamental molecular mechanisms of bipolar disorder.

List of experimentally validated miRNAs obtained from miRTarbase and HMDD v3.2 databases are shown in Table 1. Experimentally validated miRNAs and their target genes and their regulation status are seen in Table 2 and Figure. VAMP2, NR4A2, BCL2, ESR1, BDNF genes are targeted by hsa-mir-206; BCL2, RNF41, FKBP5 genes are tar-

Table 1. List of miRNAs taking role in bipolar disorder pathogenesis

\begin{tabular}{|c|c|}
\hline hsa-mir-103-1 & hsa-mir-206 \\
\hline hsa-mir-124 & hsa-mir-218-1 \\
\hline hsa-mir-132 & hsa-mir-34a \\
\hline hsa-mir-134 & hsa-mir-449a \\
\hline hsa-mir-137 & hsa-mir-652 \\
\hline hsa-mir-138 & hsa-mir-708 \\
\hline hsa-mir-15b & hsa-mir-9-3 \\
\hline
\end{tabular}


Ta ble 2. List of genes targeted by the miRNAs and their regulation status in bipolar disorder

\begin{tabular}{cll}
\hline \multicolumn{1}{c}{ miRNA } & \multicolumn{1}{c}{ Gene } & \multicolumn{1}{c}{ Regulation } \\
\hline hsa-mir-206 & VAMP2, NR4A2, BCL2, ESR1, BDNF & Downregulation \\
hsa-mir-708 & BCL2, RNF41, FKBP5 & Downregulation \\
hsa-mir-652 & CBS & Downregulation \\
hsa-mir-134 & YWHAZ, GABRB2 & Downregulation \\
hsa-mir-15b & FKBP1A, CACNA1B, BCL2, MAPK1, RTN4, MTHFR, DCTN5 & Downregulation \\
hsa-mir-34a & IMPA1, ADARB1, AKT1, CASP8, BCL2, TNF, CLOCK, RTN4, & Downregulation \\
& MAGI1, PDE4B, TGM2, PLCG1, SIRT1, VEGFA, DCTN5 & \\
hsa-mir-218-1 & P2RX7 & Downregulation \\
hsa-mir-132 & $M M P 9, M A P K 1, N C S 1, R T N 4, B D N F$, SIRT1 & Downregulation \\
hsa-mir-124 & NFIX, LMAN2L, MLLT3, EGR2, ASTN2, AKT2, ADARB1, & Downregulation \\
& SLC1A4, RGS4, ROR1, NEDD4, GRIA3, UHMK1, DISC1, & \\
& NRG1, SRSF3, CLOCK, SLC1A3, CXCL8, IMPACT, & \\
hsa-mir-449a & FGFR1, BDNF, SIRT1, VDR, NR3C2, DBNL & \\
hsa-mir-137 & RORA, DCLK1 & Downregulation \\
hsa-mir-138 & AKT1, HIF1A, BAG1, RARA, RELN & Downregulation \\
\hline
\end{tabular}

geted by hsa-mir-708; CBS gene is targeted by hsamir-652; YWHAZ, GABRB2 genes are targeted by hsa-mir-134; FKBP1A, CACNA1B, BCL2, MAPK1, RTN4, MTHFR, DCTN5 genes are targeted by hsamir-15b; IMPA1, ADARB1, AKT1, CASP8, BCL2, TNF, CLOCK, RTN4, MAGI1, PDE4B, TGM2, PLCG1, SIRT1, VEGFA, DCTN5 genes are targeted by hsa-mir-34a; $P 2 R X 7$ gene is targeted by hsamir-218-1; MMP9, MAPK1, NCS1, RTN4, BDNF, SIRT1 genes are targeted by hsa-mir-132; NFIX, LMAN2L, MLLT3, EGR2, ASTN2, AKT2, ADARB1, SLC1A4, RGS4, ROR1, NEDD4, GRIA3, UHMK1, DISC1, NRG1, SRSF3, CLOCK, SLC1A3, CXCL8, IMPACT, FGFR1, BDNF, SIRT1, VDR, NR3C2, $D B N L$ genes are targeted by hsa-mir-124; BCL2, SIRT1, DCTN5 genes are targeted by hsa-mir-449a; RORA, DCLK1 genes are targeted by hsa-mir-137; and AKT1, HIF1A, BAG1, RARA, RELN genes are targeted by hsa-mir-138.

In recent years numerous studies have highlighted the consisting of miRNA-mediated modulation of protein levels in drug response. Given the correlation we have constituted between miRNAs and bipolar disorder, we tried to identify whether miRNA target genes involved any therapeuticallyassociated lithium-targets. In this study, it has been found that GSK3B, IMPA1, IMPA2, GRIA3 genes are targeted by lithium that is used for the treatment of bipolar disorder according to DrugBank online tool (see Table 3). Lithium has an inhibitor effect on GSK3B, IMPA1, IMPA2 genes while it potentiates GRIA3 gene. According to the in silico analysis, IMPA1 gene is targeted by hsa-mir-34a and GRIA3 gene is targeted by hsa-mir-124.

The phosphatidylinositol (PI) cycle is a main intracellular second messenger system in brain and in many other tissues. The dephosphorylation of inositol-1-phosphate to inositol is executed by the enzyme called inositol monophosphatase (IMPase) [17]. IMPases are encoded by two genes, IMPA1 gene on chromosome 8q21.13-21.3 and IMPA2 gene on chromosome 18p11.2, in human [18]. It is known that lithium inhibits enzymatic activity of IMPase in vitro and in vivo and it is supposed to be associated with inositol depletion [19]. It has been found that IMPase enzyme activity and IMPA1 gene expression were altered in bipolar disorder [18]. It has been found that IMPA1 gene was inhibited by lithium and also downregulated by hsa-mir-34a according to the in silico analysis in this study.

Glutamate is one of the most significant neurotransmistter in the brain and it acts as a excitatory one. GRIA3, a subunit of ionotropic glutamate receptors, also known as $\alpha$-amino-3-hydroxy-5-methyl-4isoxazol-propionate (AMPA) receptors (AMPARs), have been fundamentally identified in the central 

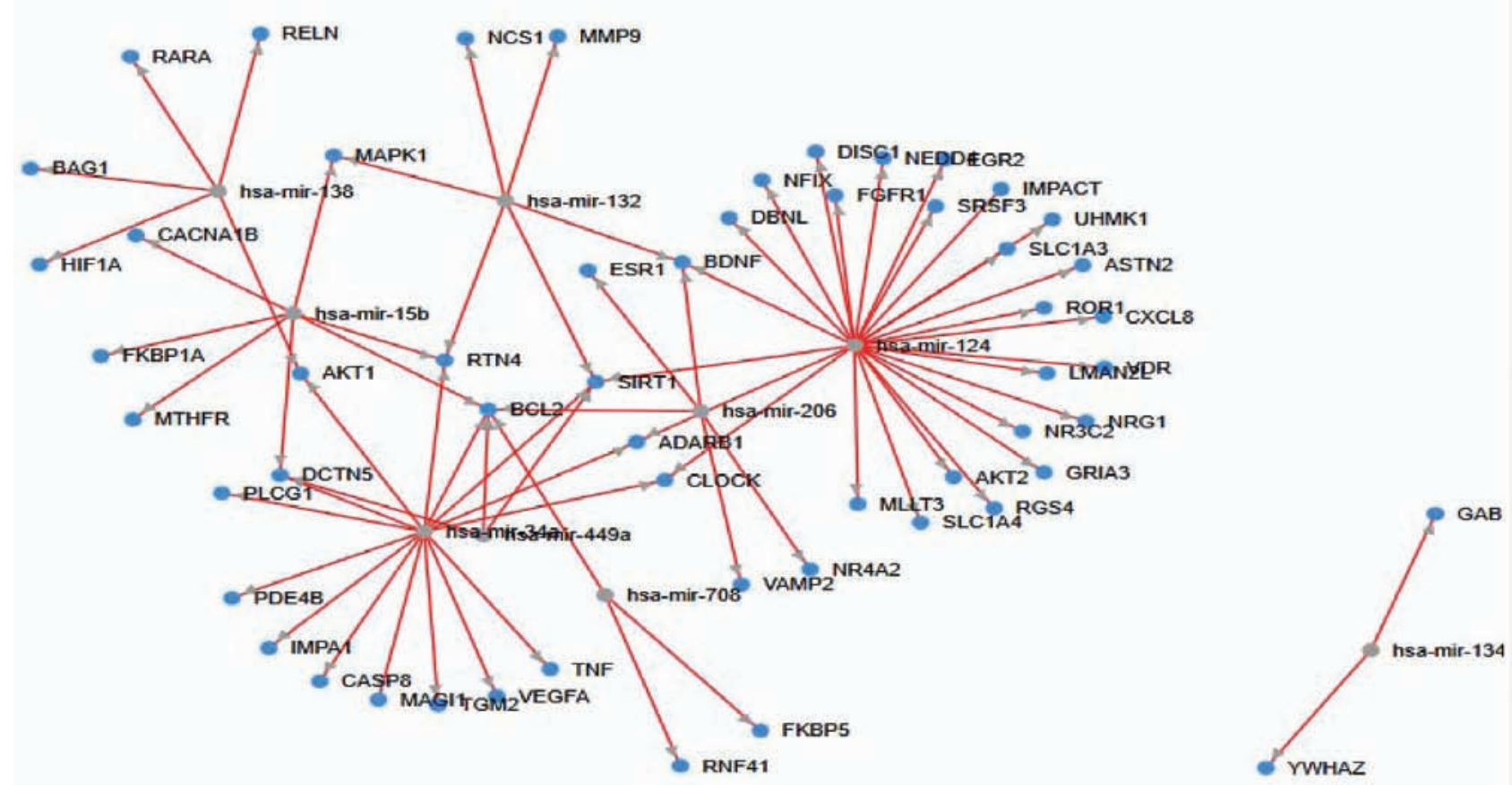

Node type (Regulatory relationship with disease)

hsa-mir-218-1

Regulation type

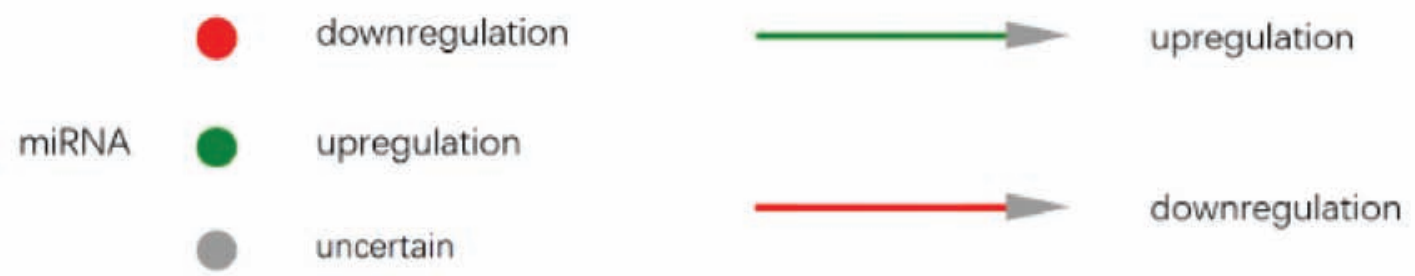

gene

Figure. The interactions between the microRNAs that are implicated in bipolar disorder and their target genes. hsa-mir-206 downregulates VAMP2, NR4A2, BCL2, ESR1, BDNF genes; hsa-mir-708 downregulates BCL2, RNF41, FKBP5 genes; hsa-mir-652 downregulates CBS gene; hsa-mir-134 downregulates YWHAZ, GABRB2 genes; hsa-mir-15b downregulates IMPA1, ADARB1, AKT1, CASP8, BCL2, TNF, CLOCK, RTN4, MAGI1, PDE4B, TGM2, PLCG1, SIRT1, VEGFA, DCTN5 genes; hsa-mir-218-1 downregulates P2RX7 gene; hsa-mir-132 downregulates MMP9, MAPK1, NCS1, RTN4, BDNF, SIRT1 genes; hsa-mir-124 downregulates NFIX, LMAN2L, MLLT3, EGR2, ASTN2, AKT2, ADARB1, SLC1A4, RGS4, ROR1, NEDD4, GRIA3, UHMK1, DISC1, NRG1, SRSF3, CLOCK, SLC1A3, CXCL8, IMPACT, FGFR1, BDNF, SIRT1, VDR, NR3C2, DBNL genes; hsa-mir-449a downregulates BCL2, SIRT1, DCTN5 genes; hsa-mir-137 downregulates RORA, DCLK1 genes; hsa-mir-138 downregulates AKT1, HIF1A, BAG1, RARA, RELN genes

nervous system [20, 21]. GRIA3 is significant mediator of synaptic plasticity and transmission and mutations in GRIA3 gene are associated with brain disturbances such as intellectual disability and sleep problems [22]. There is no study about the relatioship between GRIA3 gene and bipolar disorder and lithium response in the literature. In this study, it has been determined that GRIA3 gene was activated by lithium and was downregulated by hsa-mir-124.

Conclusions. The results in this study indicate that the relationship between IMPA1 gene and hsamir-34a and the relationship between GRIA3 gene 
Ta ble 3. Target genes of lithium and functions of the target genes and effect of lithium on the target genes

\begin{tabular}{|l|c|c|c|c|}
\hline \multicolumn{1}{|c|}{ Target } & Gene ID & General function & Action & Organism \\
\hline Glycogen synthase kinase-3 beta & GSK3B & Ubiquitin protein ligase binding & Inhibitor & Human \\
\hline Inositol monophosphatase 1 & IMPA1 & $\begin{array}{c}\text { Protein homodimerization } \\
\text { activity }\end{array}$ & Inhibitor & Human \\
\hline Inositol monophosphatase 2 & IMPA2 & $\begin{array}{c}\text { Protein homodimerization } \\
\text { activity }\end{array}$ & Inhibitor & Human \\
\hline Glutamate receptor 3 & GRIA3 & $\begin{array}{c}\text { Extracellular-glutamate- } \\
\text { gated ion channel activity }\end{array}$ & Potentiator & Human \\
\hline
\end{tabular}

and hsa-mir-124 may clarify the molecular mechanism of the variable lithium response. The present study demonstrated that IMPA1 and GRIA3 genes and hsa-mir-34a and hsa-mir-124 might serve as a predictor of the lithium response in patients with bipolar disorder. Therefore, IMPA1, GRIA3, hsa-mir34a, hsa-mir-124 may have the potential to be used as molecular biomarker for estimating and monitoring the lithium response in bipolar disorder. Moreover, further in vitro and in vivo analysis of expression of IMPA1, GRIA3, hsa-mir-34a, hsa-mir-124 may provide comprehensive information about the clinical response of lithium treatment in bipolar disorder.

Conflict of interest. Authors have completed the Unified Conflicts of Interest form at http://ukrbiochemjournal.org/wp-content/uploads/2018/12/ coi_disclosure.pdf and declare no conflict of interest.

Funding. The study has not been supported by any Grant.

\section{MPHK HSA-MIR-34A TA HSA- \\ MIR-124 ЯК БIOМАРКЕРИ \\ ДЛЯ ПРОГНОЗУВАННЯ ТА \\ МОНІТОРИНГУ ЛІКУВАННЯ \\ ЛІТІЕМ ЗА БІПОЛЯРНОГО \\ РОЗЛАДУ: АНАЛІЗ IN SILICO}

\section{Orcun Avsar}

\section{Hitit University, Department of Molecular Biology and Genetics, Corum, Turkey e-mail: orcunavsar.gen@gmail.com}

Відомо, що літій ефективно лікує психічні розлади в людей з біполярним розладом. Метою дослідження було ідентифікувати специфічні для біполярного розладу мРНК, що пов'язані $з$ генами-мішенями дії літію за лікування та зумовлюють відмінності клінічної відповіді. Екс- периментально перевірені мРНК із різним патерном експресії за біполярних розладів були відібрані із загальнодоступних онлайн-баз даних miRTarbase та HMDD v3.2. Для кожної мРНК прогнозували мішень та експериментально підтверджені пари мішень-мРНК отримували та аналізували за допомогою miRTarbase, HMDD v3.2, TargetScan та DIANA. Гени-мішені мРНК, пов'язані з дією літія, визначали за допомогою DrugBank. Аналіз in silico показав, що мішенню hsa-mir-34а був ген IMPA1, а мішенню hsa-mir-124 - був ген GRIA3. Дослідження показало, що IMPA1, GRIA3, hsa-mir-34a, hsamir-124 можуть мати потенціал молекулярних біомаркерів для оцінки та моніторингу реакції у разі лікування літієм за біполярних розладів.

Ключов і слова: біполярний розлад, літій, IMPA1, GRIA3, мРНК hsa-mir-34a, мРНК hsa-mir-124.

\section{References}

1. Forstner AJ, Hofmann A, Maaser A, Sumer S, Khudayberdiev S, Mühleisen TW, Leber M, Schulze TG, Strohmaier J, Degenhardt F, Treutlein J, Mattheisen M, Schumacher J. et al. Genome-wide analysis implicates microRNAs and their target genes in the development of bipolar disorder. Transl Psychiatry. 2015; 5(11): e678.

2. McCormick U, Murray B, McNew B. Diagnosis and treatment of patients with bipolar disorder: A review for advanced practice nurses. $J$ Am Assoc Nurse Pract. 2015; 27(9): 530-542.

3. Rowland TA, Marwaha S. Epidemiology and risk factors for bipolar disorder. Ther $A d v$ Psychopharmacol. 2018; 8(9): 251-269.

4. Reinbold CS, Forstner AJ, Hecker J, Fullerton JM, Hoffmann P, Hou L, Heilbronner U, Degenhardt F, Adli M, Akiyama K. et al. Analysis of the Influence of microRNAs in Lithium Response in Bipolar Disorder. Front Psychiatry. 2018; 9: 207. 
5. Chiu CT, Wang Z, Hunsberger JG, Chuang DM. Therapeutic potential of mood stabilizers lithium and valproic acid: beyond bipolar disorder. Pharmacol Rev. 2013; 65(1): 105-142.

6. Piedade D, Azevedo-Pereira JM. The Role of microRNAs in the Pathogenesis of Herpesvirus Infection. Viruses. 2016; 8(6): 156.

7. Alural B, Genc S, Haggarty SJ. Diagnostic and therapeutic potential of microRNAs in neuropsychiatric disorders: Past, present, and future. Prog Neuropsychopharmacol Biol Psychiatry. 2017; 73: 87-103.

8. Huang HY, Lin YCD, Li J, Huang KY, Shrestha S, Hong HC, Tang Y, Chen YG, Jin CN, Yu Y, Xu JT, Li YM, Cai XX, Zhou ZY, Chen XH, Pei YY, Hu L, Su JJ, Cui SD, Wang F, Xie YY, Ding SY, Luo MF, Chou CH, Chang NW, Chen KW, Cheng YH, Wan XH, Hsu WL, Lee TY, Wei FX, Huang HD. miRTarBase 2020: updates to the experimentally validated microRNA-target interaction database. Nucleic Acids Res. 2020; 48(D1): D148-D154.

9. Huang Z, Shi J, Gao Y, Cui C, Zhang S, Li J, Zhou Y, Cui Q. HMDD v3.0: a database for experimentally supported human microRNA-disease associations. Nucleic Acids Res. 2019; 47(D1): D1013-D1017.

10. Agarwal V, Bell GW, Nam JW, Bartel DP. Predicting effective microRNA target sites in mammalian mRNAs. Elife. 2015; 4: e05005.

11. Vlachos IS, Hatzigeorgiou AG. Functional analysis of miRNAs using the DIANA tools online suite. In: Schmidt M. (eds) Drug Target miRNA. Methods in Molecular Biology. Humana Press, New York, NY, 2017; vol. 1517.

12. Wishart DS, Feunang YD, Guo AC, Lo J, Marcu A, Grant JR, Sajed T, Johnson D, Li C, Sayeeda Z, Assempour N, Iynkkaran I, Liu Y, Maciejewski A, Gale N, Wilson A, Chin L, Cummings R, Le D, Pon A, Knox C, Wilson M. DrugBank 5.0: a major update to the DrugBank database for 2018. Nucleic Acids Res. 2018; 46(D1): D1074-D1082.

13. López-Muñoz F, Shen WW, D'Ocon P, Romero A, Álamo C. A History of the Pharmacological Treatment of Bipolar Disorder. Int J Mol Sci. 2018; 19(7): 2143.

14. Anand A, McClintick JN, Murrell J, Karne H, Nurnberger JI, Edenberg HJ. Effects of Lithium Monotherapy for Bipolar Disorder on Gene Expression in Peripheral Lymphocytes. Mol Neuropsychiatry. 2016; 2(3): 115-123.
5. Oedegaard KJ, Alda M, Anand A, Andreassen OA, Balaraman Y, Berrettini WH, Bhattacharjee A, Brennand KJ, Burdick KE, Calabrese JR, Calkin CV, Claasen A, Coryell WH, Craig D, DeModena A. et al. The Pharmacogenomics of Bipolar Disorder study (PGBD): identification of genes for lithium response in a prospective sample. BMC Psychiatry. 2016; 16: 129.

16. Kim Y, Zhang Y, Pang K, Kang H, Park H, Lee Y, Lee B, Lee HJ, Kim WK, Geum D, Han K. Bipolar Disorder Associated microRNA, miR-1908-5p, Regulates the Expression of Genes Functioning in Neuronal Glutamatergic Synapses. Exp Neurobiol. 2016; 25(6): 296-306.

17. Cryns K, Shamir A, Acker NV, Levi I, Daneels G, Goris I, Bouwknecht JA, Andries L, Kass S, Agam G, Belmaker H, Bersudsky Y, Steckler T, Moechars D. IMPA1 is essential for embryonic development and lithium-like pilocarpine sensitivity. Neuropsychopharmacology. 2008; 33(3): 674-684.

18. Sjøholt G, Ebstein RP, Lie RT, Berle JØ, Mallet J, Deleuze JF, Levinson DF, Laurent C, Mujahed M, Bannoura I, Murad I, Molven A, Steen VM. Examination of IMPA1 and IMPA2 genes in manicdepressive patients: association between IMPA2 promoter polymorphisms and bipolar disorder. $\mathrm{Mol}$ Psychiatry. 2004; 9(6): 621-629.

19. Ohnishi T, Tanizawa Y, Watanabe A, Nakamura T, Ohba H, Hirata H, Kaneda C, Iwayama Y, Arimoto T, Watanabe K, Mori I, Yoshikawa T. Human myoinositol monophosphatase 2 rescues the nematode thermotaxis mutant ttx-7 more efficiently than IMPA1: functional and evolutionary considerations of the two mammalian myo-inositol monophosphatase genes. J Neurochem. 2013; 124(5): 685-694.

20. Fang J, An X, Chen S, Yu Z, Ma Q, Qu H. Casecontrol study of GRIA1 and GRIA3 gene variants in migraine. J Headache Pain. 2015; 17: 2.

21. Ripka S, Riedel J, Neesse A, Griesmann H, Buchholz M, Ellenrieder V, Moeller F, Bart P, Gress TM, Michl P. Glutamate receptor GRIA3target of CUX1 and mediator of tumor progression in pancreatic cancer. Neoplasia. 2010; 12(8): 659-667.

22. Davies B, Brown LA, Cais O, Watson J, Clayton AJ, Chang VT, Biggs D, Preece C, Hernandez-Pliego P, Krohn J, Bhomra A, Twigg SRF, Rimmer A, Kanapin A. et al. A point mutation in the ion conduction pore of AMPA receptor GRIA3 causes dramatically perturbed sleep patterns as well as intellectual disability. Hum Mol Genet. 2017; 26(20): 3869-3882. 